\title{
Pembelajaran Bahasa Sastra Melalui Pemberdayaan Kompetensi Guru
}

\author{
Nikmatul Izah \\ Universitas Yudharta Pasuruan \\ nikmatul.izzah@yudharta.ac.id
}

\begin{tabular}{|l|l|l|}
\hline Received: November $17^{\text {th }} 2019$ & Revised: December $4^{\text {th }} 2019$ & Accepted: December $30^{\text {th }} 2019$
\end{tabular}

\begin{abstract}
Abstrak: Language has a central role in students' intellectual, social and emotional development. Languages support students' success in learning all fields of study. Therefore, language learning must be interesting and fun for students. Indonesian language and literature learning in some schools is still not in accordance with what is expected. Teachers tend to use theoretical learning techniques so learning is rigid and boring. As a result, Indonesian language and literature bave not yet become lessons that students enjoy. Literature teachers have not been able to use compelling methods. Many literary teachers lack sufficient interest and talent regarding literature. The impact of failure on students in developing, language skills, and positive attitudes towards Indonesian language and literature. Improving the quality of Indonesian education in the era of globalization must be comprehensive or comprehensive, emphasizing the implementation of the autonomy of education management, by creating various ways to achieve the objectives of national education as a whole and to immediately catch up with other countries. A tool to measure the success of a learning that is teachers who are innovative, creative and can choose the right learning points. Steps to become a creative teacher include (1) becoming an explorer of the mind, (2) developing questions (3) developing as many ideas as possible, and (4) creating an interesting and fun learning model.
\end{abstract}

Keyword: language learning, empowering teacher competencies, fun learning.

\section{Pendahuluan}

Pembelajaran sastra disekolah saat ini hanya sekedar memenuhi target kurikulum, tidak menukik pada permasalahan apresiasi sastra lebih mendalam. Keadaan ini diperparah dengan munculnya karya-karya yang mengusung ideologi dan genre tertentu. Pada awal tahun 2000-an, kita tersentak dengan lahirnya novel-novel teenlit dan chickklit. Contohnya, novel cintapucino. Novel ini begitu membahana dan menjadi bacaan dikalangan remaja saat itu. Kemunculannya sempat menjadi perbincangan kalangan sastrawan di negeri ini. 
Sebut saja naning pranoto, seorang novelis. Menurutnya, kelahiran genre novel teenlit dan sejenisnya dapat merusak karya sastra yang sebenarnya dan dapat merusak bahasa Indonesia. Seperti kita ketahui novel ini dalam mengusung ideide kreatifnya menggunakan bahasa gaul, bukan bahasa Indonesia yang baik dan benar.

Kemunculan novel bentuk ini merupakan gerakan sastra tersendiri. Hal ini juga disebabkan kurangnya pengajaran sastra disekolah-sekolah. Dengan demikian, ketika muncul alternatif bacaan dikalangan mereka, langsung ditanggapi secara positif.

Selain novel teenlit, kini muncul karya novel yang berlatar kehidupan riil dilapangan. Sebut saja Laskar Pelangi karya Andra Hirata. Dia bercerita dengan setting pedalaman pulau Balitong. Gaya naratif yang ditawarkan juga ternyata mampu memukau kalangan remaja, dan menjadikan salah satu alternatif pencerahan di tengah kehidupan glamour dan hendonistis di negeri ini.

Dalam Kamus Besar Bahasa Indonesia edisi ke delapan (2008:263), pendidikan diartikan sebagai proses pengubahan sikap dan tata laku seorang atau kelompok orang dalam usaha mendewasaka manusia melalui upaya pengajaran dan pelatihan; proses, cara, perbuatan mendidik. Hal ini, menyangkut 'dunia guru' adalah 'dunia kelas' yang secara sepihak menekan, mendesak, bahkan memaksa guru untuk melaksanakan proses pembelajaran sebagai proses pendidikan yang diharapkan dapat memanusiakan anak didik. Selain itu, guru diharapkan mampu menyajikan proses pembelajaran yang bersifat teoritis, tetapi juga memiliki efek pendamping yang berkewajiban untuk membentuk, mewarnai kepribadian, dan moral siswa.

Pembelajaran sastra di sekolah sesuai dengan kurikulum KBK dan kurikulum setelahnya pada dasarnya memiliki dua sasaran. Pertama, memberikan kompetensi kepada siswa untuk menulis karangan fiksi dan nonfiksi dengan menggunakan kosakata yang bervariasi dan efektif dan menimbulkan efek dan hasil tertentu. Kedua, pembelajaran sastra bertujuan memberikan kompetensi kepada siswa untuk mampu mengapresiasi sastra berupa puisi, prosa, dan drama. Dengan demikian diharapkan pembelajaran sastra di sekolah dapat menjadi salah satu alternatif dengan meningkatkan kadar jati diri, rasa estetik dan pendidikan moral siwa disekolah.

\section{Peran Guru Sastra}

Pemberdayaan guru sastra dalam pengertian sesungguhnya yaitu semacam seminar lokakarya, penataran, atau diklat yang cenderung formal dan kaku, tampaknya sudah tidak efektif. Forum nonformal semacam bengkel sastra 
akan lebih efektif. Mereka bisa saling berbagi pengalaman dan diskusi. Simulasi pembelajaran sastra yang ideal bisa dipraktikan bersama-sama sehingga guru sastra memperoleh gambaran konkret tentang cara menyajikan apresiasi sastra yang sebenarnya kepada siswa.

Dalam pembelajaran siswa, guru dituntut untuk menciptakan suasana pembelajaran yang PAIKEM, yaitu pembelajaran yang Aktif, Inovatif, Kreatif, Efektif, dan menyenangkan. Disamping sebagai seorang fasilitator, guru harus dapat membangkitkan perhatian peserta didik pada pengajaran sastra yang diberikan serta dapat menerapkan metode dan sumber belajar yang bervariasi. Guru harus dapat membangkitkan minat peserta didiknya untuk aktif dan produktif sebagai hasil dari respon yang dapat menghasilkan imput dan outcome sesuai dengan tujuan awal.

Guru harus dapat mengembangkan potensinya, supaya bisa berinteraksi dan menciptakan pembelajaran yang berkualitas serta melahirkan peserta didik yang berkompetensi dan berkualitas. Kompetensi yang harus dimiliki oleh seorang guru yaitu kompetensi pedagogik (guru harus mampu menguasai materi dan berwawasan luas), kompetensi profesional (guru harus bisa bekerja dan bertanggung jawab dengan profesinya sebagai seorang pendidik), kompetensi kepribadian (guru harus bisa menjadi contoh dan teladan bagi anak didiknya), kompetensi sosial (guru harus bisa bersosialisasi dan berinteraksi dengan masyarakat, teman sejawat, anak didik, maupun dengan atasannya).

Guru sastra menjadi figur sentral dalam menaburkan benih dan menyuburkan apresiasi sastra dikalangan anak didiknya. Apabila pengajaran sastra diberikan oleh guru yang tepat, imajinasi siswa akan terbawa kedalam suasana pembelajaran yang dinamis, menarik, kreatif, dan menyenangkan. Sebaliknya, jika pengajaran sastra disajikan oleh guru yang salah, situasi pembelajaran akan sangat membosankan. Imbasnya, apresiasi sastra siswa tidak akan berubah malahan akan terpuruk.

Pertanyaan yang muncul, sudah siapkah guru sastra melaksanakan kurikulum dengan benar? untuk menjawab pertanyaan itu, seharusnya pemerintah melakukan pemetaan sehingga dapat diketahui oleh guru bahasa yang memiliki kompetensi dan minat dibidang sastra yang mampu membawa dunia siswa untuk mencintai sastra.

Pada periode sebelumnya guru dianggap harus lebih multidimensi saat ini guru harus spesialis. Dengan begitu materi yang disampaikan lebih bernuansa dan menyenangkan. Guru spesialis dimata anak didik semakin tinggi nilainya karena keduanya akan berjalan seimbang dan harmonis. 


\section{Polemik Pembelajaran Sastra}

Bahasa dalam teks sastra tidaklah dominan sebagai sarana komunikasi, karena potensi bahasa dapat digunakan tanpa batasan. Karena itu, kalimat dalam karya sastra sering bersifat ambigu, abstrak, simbolis dan inkonvensional. Dngan demikian, dapat disebukan bahwa dalam menjelmakan aspek estetika, bahasa sering disusun melalui permainan kata yang direfleksikan dengan ungkapan makna yang bersifat imajinatif.

Sastra sebagai sebuah karya memiliki sifat universal, demikian juga dengan pemaknaan karya tersebut. Seorang apresiator memiliki hak untuk mengulas karya dari berbagai sudut pandang masing-masing. Tetapi yang menjadi permasalahan saat ini adalah bagaimana pendidik khususnya bidang studi sastra menghadapi polemik. Benar-benar dibutuhkan kesungguhan dalam pengajaran sastra, kekreatifan gurulah yang memunculkan jurus-jurus inovatif yang akan mengubah paradigma keterpasungan talenta guru.

Perubahan selalu berkembang sesuai dengan peradapan dan perkembangan jaman. Manusia akan meninggalkan sejarahnya tanpa adanya buku. Keberadaan sastra, bacaan sastra dan tradisi membaca mulai hilang dengan adanya perkembangan jaman yang semakin canggih. Modernnya ilmu teknologi, semakin menggerus dunia sastra. Dengan perkembangan jaman keterpurukan buku dan tulisan akan segera ditinggalkan. Zaman yang melenial ini semakin melekat dan membudidaya dalam diri masyarakat sekarang.

Disamping ilmu pengetahuan dan teknologi yang sedang membalut kita saat ini, seni sastra tidak dapat dipungkiri keberadaannya bahwa seni mempunyai peranan yang penting dalam meningkatkan kesejahteraan hidup suatu bangsa dan negara. Kepribadian dan identitas suatu masyarakat atau bangsa dapat diaplikasikan melalui seni. Kehidupan sastra suatu bangsa meliputi aspek penciptaan yang menggabungkan sastrawan, penelitian (pengamatan) yang melibatkan para peneliti, dan para penikmatkarya sastra itu sendiri. Pengajar sastra merupakan seorang intelek yang produktif, sedangkan anak didik merupakan seorang penerima yang berfungsi mengaplikasikan sebagai suatu identitas diri yang merupakan suatu proses berfikir.

Seharusnya aspek-aspek kesusastraan berjalan dengan dinamis dan seimbang. Kenyataannya tidak demikian. Pengajaran sastra menjadi permasalahan dan keluhan di tingkat sekolah saat ini karena kurang optimal dalam mencapai tujuan yang produktif. Pembelajaran sastra saat ini kebanyakan hanya membahas dari segi strukturnya saja yaitu unsur intrinsik dan unsur ekstrinsik. Guru sebagai seorang pendidik dianggap kurang memiliki kompetensi (pengetahuan) sastra yang luas. Seorang guru kurang inovatif dan kreatif 
memberikan pemahaman tentang sastra. Ruang lingkup dan gerak pengajaran sastra hanya terbatas pada silabus dan SKL. Model dan sistem pembelajaran sudah diatur secara rinci di dalam silabus. Pada hakikatnya, seorang guru tidak bisa menjadi seorang intelek yang produktif dan bisa menjadi stimulus kepada peserta didiknya mengenai pengajaran sastra yang produktif. Seorang guru tidak bisa bereksplorasi secara luas dan hanya fokus pada silabus yang menjadi pedoman dalam sistem pembelajaran yang mempersempit kreativitas seorang guru.

Disamping itu, bermuara pada apresiasi dan minat baca peserta didik yang masih rendah terkait dengan karya-karya sastra. Karya sastra semakin tergeser dan dikesampingkan, bahkan dianggap kurang penting. Minat baca dan menulis anak didik mulai di lupakan. Sastra hanya dianggap sebagai hiburan dan pelengkap mata pelajaran di sekolah. Peserta didik lebih mencintai dan mempelajari bahasa asing (Inggris) dibandingkan dengan bahasanya sendiri (Indonesia) yang diaplikasikan melalui sastra yang justru sebagai budaya dan identitas Indonesia. Pengetahuan dan pemahaman sastra bahkan masih sedikit dan sanagt sempit dibandingkan dengan dunia teknologi, dunia yang menyulap panggung teater manusia.

Beralih dari aspek guru, sudut pandang lain berdalih pada sistem pendidikan dan kurikulum pendidikan saat ini yang tidak pernah memberikan ruang gerak yang cukup pada pembelajaran sastra. Padahal, pengajaran sastra sebagai wadah untuk generasi yang akan datang untuk melahirkan sastrawan, kritikus, penulis, maupun dosen agar tetap produktif dan tidak tergeser oleh derasnya arus zaman.

Tampaknya pembelajaran sastra di sekolah dewasa ini hanya sekedar memenuhi target kurikulum, tidak menukik pad permasalahan apresiasi sastra lebih mendalam. Kondisi ini lebih diperparah dengan munculnya karya-karya yang mengusung genre tertentu. Awal tahun 2000-an, kita tersentak dengan lahirnya novel-novel teenlit, contohna Cintapucino. Teenlit dan sejenisnya mengusung tema-tema baru, ide-ide kreatifnya menggunakan bahasa gaul, bukan bahasa Indonesia yang baik dan benar. Hal ini juga disebabkan kurangnya pengajaran sastra disekolah-sekolah. Dengan demikian, ketika muncul alternatif bacaan di kalangan mereka, langsung ditanggapi secara positif.

Pembelajaran bahasa dan sastra di Indonesia disebagian sekolah belum berlangsung seperti yang dihsrapkan. Guru cenderung menggunakan teknik pembelajaran yang teoretis dan hafalan sehingga kegiatan pembelajaran berlangsung kaku, monoton, dan membosankan. Mata pelajaran bahasa dan sastra Indonesia belum mampu melekat pada diri siswa sebagai sesuatu yang 
rasional, kognitif, emosional, dan afektif. Akibatnya, bahasa dan sastra Indonesia belum mampu menjadi mata pelajaran yang disenangi dan dirindukan oleh siswa. Imbas lebih jauh, kegagalan siswa dalam mengembangkan pengetahuan, keterampilan berbahasa, dan sikap positif terhadap bahasa sastra indonesia.

Pandangan tentang pembelajaran sastra pernah disampaikan Prof Suwarsih Madya. Menurutnya, pengajaran sastra dapat memberikan andil yang signifikan terhadap keberhasilan pengembangan manusia yang diinginkan asal dilaksanakan dengan pendekatan yang tepat, yaitu pendekatan yang dapat merangsang oleh hati, olah rasa, olah pikir, dan olahraga.

Pembelajaran bahasa Indonesia dan apresiasi sastra berperan sangat penting dalam pembelajaran bahasa indonesia. Hal ini terbukti dalam kurikulum 1968 sampai sekarang, apresiasi sastra merupakan materi pembelajaranyang harus diajarkan kepada siswa mulai sekolah dasar sampai sekolah lanjutan tingkat atas.

Pembelajaran sastra sebenarnya mempunyai dua tujuan. Pertama, pengetahuan sastra diperoleh dengan membaca teori, sejarah, dan kritik sastra. Kedua, pengalaman sastra dengan cara membaca melihat pertunjukan karya sastra dan menulis karya sastra.

\section{Pembelajaran Apresiasi Sastra yang Menyenangkan}

Dalam setiap proses pembelajaran, selalu akan ada tiga komponen pentingyang terkait satu sama lain. Tiga komponen penting itu adalah: (1) Kurikulum, terkait materi yang akan diajarkan, (2) proses, terkait bagaimana materi akan diajarkan, dan (3) produk, terkait hasil dari proses pembelajaran.

Pembelajaran sejarah sastra bagi sebagian siswa dianggap sebagai pembelajaran yang membosankan karena dalam pembelajarannya berkisar pada nama pengarang dan hasil karyanya serta periodesasi sastra. Untuk mengatasi masalah tersebut para pendidik sastra perlu bekerja keras menciptakan pembelajaran sejarah sastra yang menyenangkan dan berkesan pada jiwa siswa. Salah satunya dengan cara mengaitkan kecerdasan siswa dengan pengalaman apresiasi sastra. Tentu saja memerlukan kreativitas yang tinggi. Kreativitas merupakan mesin pertama bagi pendidik sastra untuk mengembangkan pembelajaran sejarah sastra yang kreatif.

Kehadiran sejarah sastra dapat mengembangkan wawasan dan imajinasi siswa. Pengetahuan sejarah sastra dapat memudahkan siswa mengapresiasi sastra. Terutama pengetahuan tentang penciptaan dan latar belakang penyair. Pengetahuan erat kaitannya dengan kecerdasan. Selain itu, latar belakang terjadinya karya sastra mampu mengembangkan imajinasi walaupun bertahun- 
tahun peristiwa itu terjadi. Hal ini terlihat melalui karya-karya sastra yang diangkat menjadi film. Imajinasi akan berkembang ketika siswa menanggapi karya sastra yang lahir pada angkatan Balai Pustaka. Demikian pula dengan para penyair dan karyanya.

\section{Perangsang Sikap Positif Siswa sebagai Langkah Awal}

Langkah awal apa yang menjadi preoritas pertama dalam hal membuat pembelajaran (apresiasi) sastra menjadi menyenangkan? misalnya faktor penghargaan menjadi hal yang diutamakan. Apresiasi sastra berarti kegiatan menikmati karya sastra secara sunguh-sungguh sehingga dalam diri siswa tumbuh kepekaan perasaan dan penghargaan terhadap karya sastra. Dengan demikian seorang guru dapat membuat pembelajaran sastra lebih menyenangkan yang dapat mengikat siswa pada sebuah kegiatan yang mengasyikkan. Pembelajaran sastra yang menarik yaitu pembelajaran yang dapat mengikat siswa terus menerus bergairah untuk melakukan kegiatan apresiasi. Akibatnya siswa akan senang, aktif, dan bersemangat mengikuti pembelajaran apresiasi sastra.

Dalam pembelajaran sastra, sikap dan prilaku siswa sebagai subjek mengaapresiasi sastra memegang peranan penting. Untuk itu guru seharusnya menciptaan suasana yang kondusif bagi munculnya sikap positif siswa. Adapun sikap positif siswa diantaranya: (a) adanya kegembiraan, keantusiasan dan semangat untuk membaca sastra, menyimak pembacaan karya sastra atau melihat pementasan sastra; (b) rasa simpatik dan peduli terhadap karya sastra dalam kegiatan apresiasi sastra; (c) keyakinan terhadap mamfaat membaca karya sastra dalam kegiatan apresiasi sastra; (d) adanya kesungguhan, keseriusan untuk terlibat dengan karya sastra dan kegiatan apresiasi sastra; dan (e) munculnya kemauan, kesiapan untuk masuk dalam kegiatan apresiasi sastra.

Tentu saja, sikap positif ini tidak terjadi begitu saja, guru harus mampu menumbuhkan sikap positif pada siswa. Bagaimana caranya? caranya sebai berikut:

1. Menghilangkan kesan dan suasana yang terlampau kaku, formal, angker dan keseriusan yang berlebihan. Hal ini merupakan prasyarat dimana siswa dikondisikan sedemikian rupa dalam suasana senang, rileks, terhibur tanpa ada kesan asal-asalan.

2. Memberikan pengalaman yang berkesan, menyenangkan, memikat, dan menyegarkan. Hal ini dapat dilakukan guru dengan memberikan pemodelan lansung seperti membaca puisi, cerpen, atau menonton drama, mengajak siswa untuk menyajikan puisi, mengajak siswa untuk berdialog dengan pengarang. 
3. Memberikan iklim, suasana, situasi, dan lingkungan apresiasi sastra yang baik dalam arti menyenangkan.

4. Menunjukkan dan memberikan contoh mamfaat dan nilai guna karya sastra dalam kegiatan apresiasi sastra. Hal ini dapt dilakukan dengan cara menginformasikan sisi hiburan dan renungan (nilai-nilai kemanusiaan) sebuah karya sastra, mempertemukan siswa dengan orang yang telah memperoleh manfaat dari membaca karya sastra atau menjelaskan langsung segi-segi positif jika membaca karya sastra.

5. Mengondisikan dan memberikan perlakuan tertentu yang dapat mengarahkan siswa untuk mendekati, membaca, dan menikmati karya sastra. Hal ini dapat dilakukan dengan caramemberikan tugas membuat ulasan sastra dengan berkelanjutan.

\section{Bahan Karya Sastra yang Menarik Sesuai Kondisi Siswa}

Ketika siswa sudah mulai menikmati pembelajaran sastra, sebaiknya guru mempertahankan kondisi siswa. Untuk itu guru dituntut untuk memperbarui bacaan, contoh, bahan atau teks sastra baik melalui buku, internet, media masa maupun cerita-cerita rakyat yang ada dilingkungan sekolah atau siswa.

Membuat bahan ajar sendiri yang funsinya sebai rambu-rambu untuk menentukan bahan agar tidak terjadi pengulangan, penyesuaian dengan tingkat pengetahuan dan pemahaman siswa, serta mempertimbangkan perkembangan kesusastraan Indonesia. Pemilihan bahan ajar harus mencakup pula berbagai genre sastra mulai dongeng (sastra lama), cerpen, novel, puisi, drama ataupun, esai. Juga perlu dikenalkan hasil sastra terjemahan dari sastra daerahdan sastra asing.

Untuk meningkatkan apresiasi sastra jumlah buku yang dibaca juga harus diperhitungkan (dalam setiap bentuk, tingkat kelas atau usia) dan mengedepankan nilai-nilai moral tertentu. Secara umum kriteria buku bahan ajar sebagai berikut:

a. Kualitas sastra dan daya tarik buku yang dibaca

b. Sesuai dengan tuntutan kurikulum

c. Menunjukkan perkembangan sastra Indonesia

d. Mempunyai kesesuian budaya dan nilai moral Indonesia

e. Sesuai dengan perkembangan psikologi dan kemampuan anak (kompetensi membaca siswa)

Buku bahan ajar haruslah mempunyai kualitas sastra dan daya tarik untuk dibaca. Sastra (novel, cerpen, puisi,dll) haruslah memiliki kriteria sastrawi atau punya estetika sastra yang tinggi sehingga mengundang minat baca siswa. 
Misalnya karya sastra indonesia seperti Siti Nurbaya, Salah Asuhan, Atheis, puisipuisi chairil anwar,dsb.

Selain itu buku bahan ajar sastra yang tergolong greet book juga perlu dimasukkan seperti Mahabharata, Ramayana, karya-karya besar seperti William Shakespeare, Charles Dicken, dsb. Bisa saja menyertakan sastra-sastra pop yang dianggap punya estetika tinggi yang telah dikenal seperti Dilan (diera 1990 an), ainun dan Habibi, Lupus, Ali Topan, Sidoel Anak Betawi, Cintaku dikampus biru,karya Mira W, Marga T, dsb.

Bahan ajar sastra juga harus sesuai dengan tuntutan kurikulum. Tuntutan kurikulum harus bisa diimplementasikan secara nyata lewat bahan ajar sastra. Misalnya dalam sastra drama, apabila dalam kurikulum ada tuntutan agar siswa melakukan pertunjukan drama maka harus dipilih bahan ajar sastra berupa teks drama yang memungkinkan untuk dipentaskan.

Selanjutnya, Bahan ajar sastra harus mempertimbangkan psikologi siswa dan kemampuan membaca siswa. Bahan ajar sastra dipilih tidak terlampau berat (sesuai jenjang kelas), tidak mengandung filsafat yang terlampau rumit, kalaupun harus berfilsafat (misalnya pada karya tertentu seperti novel-novel Iwan Simatupang) guru sebaiknya mendampingi, bersikap sebagai kamus atau menceritakan ualang dengan bahasa yang lebih mudah. Apabila guru dapat memilih bahan teks sastra yang dekat dan akrab dengan siswa, siswa dengan sendirinya tertarik, senang, dan semangat. Dengan demikian, pembelajaranpembelajaran apresiasi sastra dapat berlangsung dengan menyenangkan jauh dari rasa keterpaksaan dan siswa dapat benar-benar menikmati dan merasa senang.

\section{Membentuk Guru yang Kreatif}

Meningkatkan mutu pendidikan Indonesia pada era globalisasi haruslah secara komperehensif atau menyeluruh, dengan menitik beratkan pelaksanaan pada otonomi pengolaan pendidikan,dengan memikirkan serta melakukan berbagai cara agar tercapainya tujuan pendidikan nasional secara utuh dan untuk secepatnya mengejar ketertinggalan dari negara lain. Untuk melihat keberhasilan pembelajaran, komponen pembalajaran yang diperlukan adalah alat penilaian. Alat penilaian yang dapat digunakan untk meningkatkan kemampuan siswa meaih standar kompetensi yang sangat beragam. Guru yang inofatif dapat memiliki alat penilaian yang cocok dengan pokok pembelajarannya.

Dua aspek yang penting dalam pembelajaran sastra indonesia yaitu aspek hiburan dan kebemanfaatan. Metodologi mengajar sastra Indonesia harus terus menerus diperbarui melalui kegiatan kreasi dan inofasi guru. Pembelajaran sastra Indonesia yang ada disekolah diharapkan agar siswa kelak dapat: 
- Menikmati dan memanfaatkan karya sastra untuk memperluas wawasan, memperhalus budi pekerti, serta meningkatkan pengetahuan dan kemampuan berbahasa.

- Menghargai dan membanggakan sastra Indonesia sebagai khazanah budaya dan intelektual manusia Indonesia.

Guru sastra Indonesia juga harus menyusun rencana pembelajaran, melaksanakan kegiatan pembelajaran, mengevaluasi, menganalisis hasil evaluasi, dan melakukan tindak lanjut karena pada era globalisasi guru menjadi penentu keberhasilan siswa dalam mengadopsi dan menumbuhkembangkan nilai nilai kehidupan yang hakiki.

Pembelajaran sastra Indonesia diperlukan sentuhan hati seorang guru yang selalu dapat melakukan dengan orientasi pencapaian kompetensi anak didik yang berakhir dengan pembelajaran meningkat, kompetensi anak didik yang dapat diukur dalam sikap, pengetahuan dan keterampilan dalam berbahasa Indonesiabyang baik, benar dan sopan.

\section{Kompetensi Guru Sastra}

Kompetensi guru harus betul-betul memahami materi yang yang akan disampaikan. Selain itu, guru harus memahami karakteristik siswa yang akan diajar. Guru harus memahami lingkungan, dan kemampuan siswa. Belajar bukanlah proses untuk menjadikan siswa sebagai ahli pada disiplin Ilmu tertentu. Belajar adalah proses agar siswa dapat menemukan potensi dan jati dirinya terhadap disiplin Ilmu. Dengan belajar, siswa seharusnya mendapatkan ruang yang lebih besar untuk menambah pengalaman. Siswa lebih membutuhkan pengalaman dalam belajar, bukan pengetahuan.

Oleh karena itu, guru sastra harus memiliki kompetensi yang cukup dalam proses pembelajaran. Dukungan kompetensi guru sastra yang memadai pada akhirnya akan meniadakan problematika pembelajaran yang bertumpu pada kurikulum dan garis besar program pengajaran. Kompetensi guru adalah titik sentral proses pembelajaran saat ini. Kompetensi guru sastra harus sesuai pada kemampuan guru dalam mengajarkan materi pelajaran secar menarik, inovatif, dan kreatif yang mampu membangkitkan kegairahan siswa dalam belajar.

Guru yang kompeten adalah guru yang dapat mengubah kurikulum pembelajaran menjadi unit pelajaran yang mampu menembus ruang-ruang kelas. Kelas sebagai ruang sentral interaksi guru dan siswa harus semangat dan bergairah. Kurikulum tidak tidak semestinya mengungkung kreativitas guru dalam mengajar. Kurikulum harus benar-benar dapat mewujudkan dalam praktik 
kegiatan belajar-mengajar yang optimal, tidak hanya menjadi simbol dalam memenuhi target pembelajaran.

Pembelajaran di sekolah saat ini hanya mengarah pada penguasaan materi pembelajaran harus dapat diubah menjadi kompetensi siswa. Cara mengajar guru hanya sekedar duduk di depan kelas atau bertumpu pada ceramah menjadi bukti kurangnya kompetensi guru. Penciptaan suasana belajar yang dinamis, produktif, dan profesional harus menjadi spirit bagi para guru. Dengan demikian, guru memang pantas menjadi sosok yang dapat membentuk kepribadian siswa yang kokoh, baik secara intelektual, moral maupun spiritual. Pentingnya kompetensi guru ini juga ditegaskan dalam UU No. 14/2005 tentang guru dan dosen, yang menyatakan "Guru harus memiliki kompetensi pedagogis, profesional, sosial, dan kepribadian.

Proses pembelajaran dikelas yang monoton dan membosankan, harus diakui lebih banyak disebabkan oleh lemahnya sikap guru dalam mengajar. Siswa yang malas mengikuti pelajaran tertentu lebih banyak dipengaruhi oleh sikap guru yang acuh terhadap mat pelajarannya sendiri. Kondisi ini menjadikan siswa tidak bergairah saat mengikuti pelajaran dikelas. Konsekuensinya, siswa tidak memiliki kesadaran dan pemahaman akan pentingnya mata pelajaran yang diajar guru tersebut.

Dalam mengajar, guru bahasa bukan hanya sekedar menentukan isi dan struktur pengajaran. Mereka juga menentukan bagaimana bahasa itu diajarkan. Di sini guru berhadapan dengan metodologi. Dengan menggunakan metode yang dipilihnya, guru berupaya mengatur strategi belajar mengajar bahasa.

Upaya membenahi sikap guru dalam mengajar menjadi sangat penting. Sikap guru merupakan cerminan kualitas dan profesionalisme guru dalam proses pembelajaran. Oleh karena itu, beberapa indikator penting bagi guru untuk membenahi sikap dalam mengajar antara lain adalah: 1) memiliki orientasi pembelajran yang bersifat praktis, bukan teoristik, 2) kegiatan belajar yang harus bertumpu pada siswadalm memperoleh pengalaman, 3) berorientasi pada kompetensi siswa yang sesuai dengan kompetensi guru, 4) kemampuan menyederhanakan materi pelajaran, 5) melbatkan aspek kreativitas dalam kegiatan belajar, 6) menerapkan sistem evaluasi belajr yang dapat diukur siswa, dan 7) memiliki metode pembelajaran yang menarik dan menyenangkan.

Sebagi guru yang layak digugu dan ditiru apabila guru mempinyai sikap yang positif dalam mengajar. Masudnya guru mengajar harus melibatkan hati dalam mengajar, tidak cukup hanya pikiran. Kompetensi dan sikap guru adalah hal penting untuk profesi guru saat ini dan masa mendatang. Caranya, guru 
harus lebih membuka diri untuk terus balajar, kreatif dalam mengajar, dan menyetarakan pengetahuan dan cara mengajar.

Adapun kompetensi untuk menjadi guru sastra yang kreatif diperlukan keprofesionalannya yaitu:

a. Kompetensi pedagogik: kemampuan mengelola pembelajaran peserta didik yang meliputi pemahaman terhadap anak didik, perancangan dan pelaksanaan pembelajaran, evaluasi hasil belajar, dan pengembangan anak didik untuk mengaktualisasikan berbagai potensi yang dimilkinya.

b. Kompetensi sosial: kemampuan pendidik sebagai bagian dari masyarakat untuk berkomunikasi dan bergaul secara efektif dengan ank didik, sesama pendidik, tenaga kependidikan, orang tua wali anak didik, dan masyarakat sekitar.

c. Kompetensi kepribadian: kemampuan kepribadian yang mantap stabil, dewasa, arif, dan berwibawa, serta teladan bagi anak didik dengan berakhlak mulia.

d. Kompetensi profesional: kemampuan penguasaan materi pembelajaran secara luas dan mendalam yang memungkinkannya membimbing anak didik memenuhi standar kompetensi yang ditetapkan dalam Standar Nasional Pendidikan.

\section{Penutup}

Rendahnya kualitas pembelajaran apresiasi sastra di sekolah tidak lepas dari kurangnya guru sastra yang memiliki 'talenta' dan minat terhadap sastra. Sastra erat kaitannya dengan bahasa, proses penyajiannya perlu kreativitas dalam model penyajian yang tepat. Penyajian puisi misalnya, selain dituntut menguasai bahan ajar, guru harus mampu mencontohkan yang memikat dan sugestif saat membaca puisi. Hal ini sulit dilakukan guru yang tidak punya minat dan talenta yang cukup mengenai sastra.

Pemberdayaan guru sastra harus benar-benar diutamakan. Sebagai guru sastra harus benar-benar memilki kompetensi dan kualifikasi untuk menyajikan pembelajaran apresiasi sastra dengan baik. ditunjang dengan pemilihan bahan ajar yang relevan agar dapat terciptanya proses pembelajaran yang menyenangkan. Meningkatkan kualitas pendidikan Indonesia pada era globalisasi haruslah secara koperehensif atau menyeluruh, dengan menitikberatkan pelaksanaan pada otonomi pengelolaan pendidikan, dengan menciptakan berbagai cara agar tercapainya tujuan pendidikan nasional secara utuh dan untuk secepatnya mengejar ketertinggalan dari negara lain. Alat untuk mengukur 
keberhasilan suatu pembelajaran yaitu guru yang inovatif, kreatif dan dapat memilih pokok pembelajaran yang tepat.

Langkah untuk menjadi guru yang kreatif diantanya:

1. Jadilah penjelajah pikiran

Maksudnya jadilah guru yang terbuka dengan gagasan atau kemungkinan baru. Menciptakan dan mengembangkan gagasan yang berbeda untuk meningkatkan kualitas pembelajaran siswa.guru yang kreatif mempunyai banyak cara untuk mengatasi kelemahan dalam pembelajaran.

2. Kembangkan pertanyaan

Guru kreatif harus menpunyai banyak pertanyaan yang harus dicari jawaban untuk menyelesaikan masalah. Dengan demikian guru kreatif akan terus berkembang dan akan menghasilakan cara yang lebih baik untuk peningkatan kualitas belajar siswa.

3. Kembangkan gagasan sebanyak-banyaknya

Guru kreatif akan selalu mencari banyak solusi dan alternatif. Mengembangkan kreativitas dan imajinasi untuk meningkatkan kualitas pembelajaran.

4. Ciptakan model pembelajaran yang menarik dan menyenangkan

Seorang guru yang kreatif akan selalu berpatokan pada Learning is fun. Selalu menciptakan model dan metode pembelajaran yang menyenangkan sehingga anak didiknya merasa senang dan merasa tertarik dengan pembelajaran.

Kesimpulannya guru yang menyenangkan adalah guru yang selalu menciptakan ide-ide baru untuk membuat anak didiknya tidak merasa bosan dan monoton. Caranya mengajar dengan hati selain pikiran. Sealin itu kompetensi dan sikap guru adalah cara penting sebagai guru saat ini dan masa mendatang. Lebih membuka diri untuk terus belajar, kreatif dalam mengajar, dan menyertarakan pengetahuan. 
130 | Volume 10, Nomor 2, Desember 2019

\section{Daftar Pustaka}

Baksin, Askurifai. 2008. Aplikasi Praktis Pengajaran Sastra. Bandung: Pribumi Mekar

Brown, H. Douglas. 2008. Prinsip Pembelajaran dan Pengajaran Bahasa. Jakarta: Kedutaan Besar Amerika Serikat.

Fananie, Zainuddin. 2002. Telaah Sastra.Surakarta: Muhammadiah University Press.

Gunawan, Adi. 2006. Genius Learning Strategy. Jakarta: Gramedia Pustaka Utama.

Hamalik, Oemar. 2003. Perencanaan Pengajaran Berdasarkan Pendekatan Sistem. Jakarta: Bumi aksara.

Purwanto, M. Ngalim. 2003. Ilmu pendekatan teoritis dan praktis. Bandung: Remaja Rosdakarya.

Pusat Bahasa: Departemen Pendidikan Nasional. 2008. Kamus Besar Bahasa Indonesia. Jakarta: Balai Pustaka.

Sumiati dan Asra.2007. Metode Pembelajaran. Bandung: Wacana Prima.

Widijanto, Tjahjono.2007. Pengajaran Sastra yang Menyenangkan. Bandung: Pribumi Mekar. (http://ganeca.blogspirit.com)

Yulianto, Bambang. 2008. Pengantar Teori Belajar Bahasa. Surabaya: Unesa University Press. 